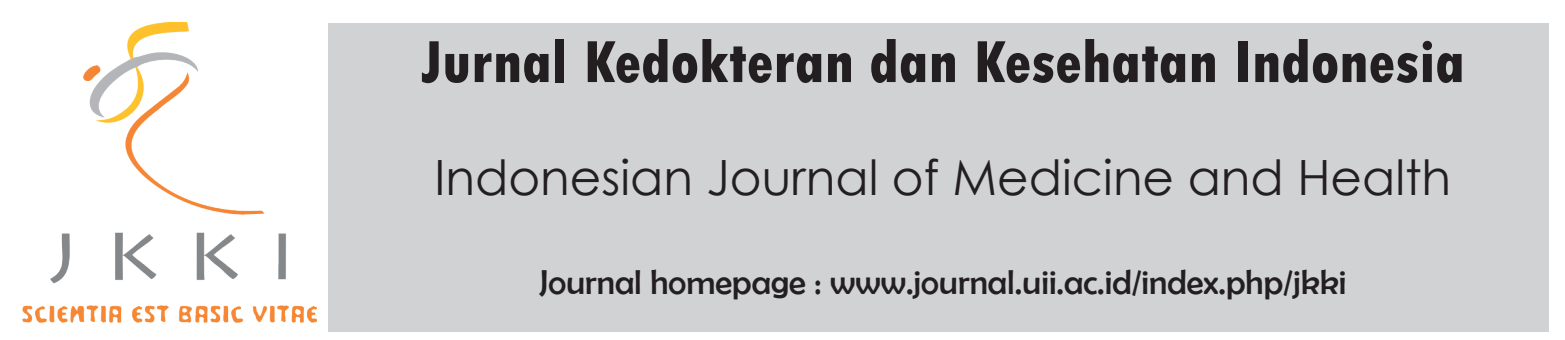

\title{
Antibiotic susceptibility of Salmonella, Shigella and Vibrio isolated from diarrhea patients in Jakarta, Indonesia
}

Meiyanti ${ }^{1}$, Oktavianus Ch. Salim² ${ }^{2}$ Elly Herwana ${ }^{1}$, Joice V.Kalumpiu ${ }^{1}$, Murad Lesmana ${ }^{3}$

${ }^{1}$ Department of Pharmacology, Faculty of Medicine, Trisakti University

${ }^{2}$ Department of Public Health, Faculty of Medicine, Trisakti University

${ }^{3}$ Department of Microbiology, Faculty of Medicine, Trisakti University

Original Article

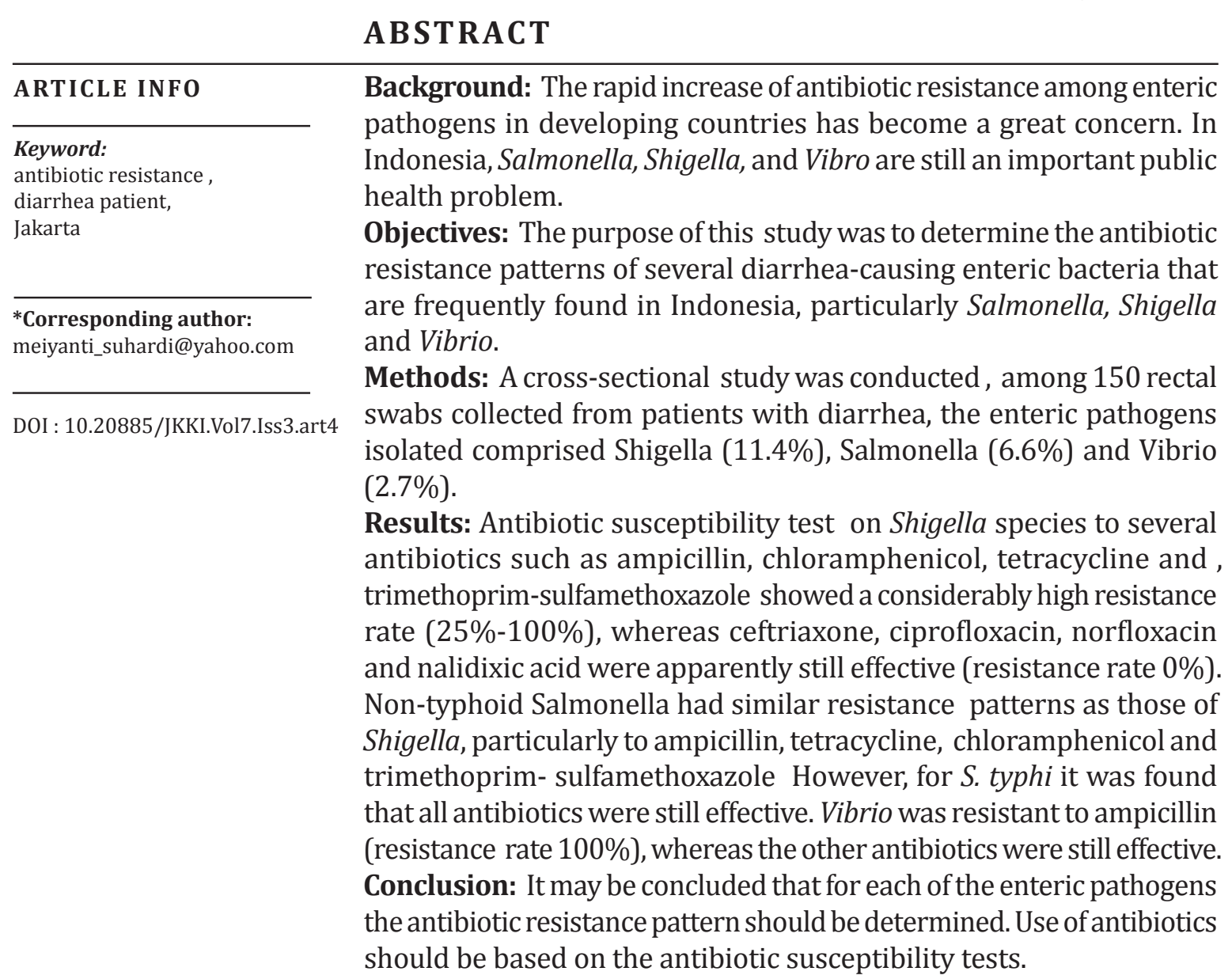

Latar Belakang: Peningkatan pesat resistensi antibiotik antara patogen enterik di negara berkembang telah menjadi perhatian besar. Di Indonesia, Salmonella, Shigella, dan Vibro masih merupakan masalah kesehatan masyarakat yang penting.

Tujuan: Tujuan dari penelitian ini adalah untuk menentukan pola resistensi antibiotik dari beberapa bakteri enterik penyebab diare yang sering ditemukan di Indonesia, khususnya Salmonella, Shigella dan Vibrio.

Metode: Sebuah studi cross-sectional dilakukan, antara 150 penyeka duburyang dikumpulkan dari 
pasien dengan diare, patogen enterik terisolasi terdiri Shigella (11,4\%), Salmonella (6,6\%) dan Vibrio $(2,7 \%)$.

Hasil: Uji kepekaan antibiotik pada spesies Shigella beberapa antibiotik seperti ampisilin, kloramfenikol, tetrasiklin dan, trimethoprimsulfamethoxazole menunjukkan tingkat resistensi yang cukup tinggi (25\%-100\%), sedangkan ceftriaxone, ciprofloxacin, norfloksasin dan asam nalidiksat yang tampaknya masih efektif (resistensi tingkat 0\%). Salmonella non-tifoid memiliki pola resistensi yang sama seperti orangorang dari Shigella, khususnya terhadap ampisilin, tetrasiklin, kloramfenikol dan trimethoprimsulfametoksazol Namun, untuk S. typhi ditemukan bahwa semua antibiotik masih efektif. Vibrio adalah resisten terhadap ampisilin (tingkat resistensi 100\%), sedangkan antibiotik lain yang masih efektif.

Kesimpulan: Dapat disimpulkan bahwa untuk setiap enterik yang patogen pola resistensi antibiotik harus ditentukan. Penggunaan antibiotik harus didasarkan pada uji kepekaan antibiotik

\section{INTRODUCTION}

Antibiotic treatment against bacterial infections is generally an important factor in reducing the morbidity and mortality rates. However, excessive and incorrect use of antibiotics for the treatment of disease may increase the occurrence of bacterial resistance to these antibiotics. ${ }^{1,2}$ This results in reduced benefits and efficacy of antibiotics commonly used in therapy, thus causing serious problems, such as a longer course of the infectious disease and unnecessary exposure of the patient to drug toxicity.

Antibiotic resistance may cause inappropriate selection of antibiotics at the start of treatment, as antibiotic administration is done empirically. The results of the treatment are unsatisfactory due to of the ineffectiveness of the antibiotic against already resistant bacteria. This problem becomes important because of increased prevalence of resistance againts antibiotic drugs commonly used in the treatment of infectious disease. The development of antibiotic resistance is accelerated by the use of antibiotics in animals and their inappropriate use in humans. ${ }^{3}$ The rapid and continuous occurrence of antibiotic resistance in enteric pathogenic bacteria to firstline antibiotics for the treatment of diarrhea has caused various problems and concerns in developing countries. ${ }^{1,4}$

In developing countries the diarrheacausing enteric pathogenic bacteria, such as Salmonella, Shigella and Vibrio, still constitute an important public health problem. ${ }^{4}$ Although Salmonella infections are self-limiting, i.e. the patient recovers after a time without specific treatment, the disease may be severe and fatal, so that antibiotics are needed. ${ }^{5-7}$ In addition, there are reports from various countries of increased resistance rates and the occurrence of multiresistance in Salmonella. ${ }^{8}$ In cases of infections caused by Shigella, high mortality rates have been reported as well as malnutrition and growth disturbances in children as a result of the disease. ${ }^{9}$ Shigellosis is related to poor hygiene, poverty and crowded housing. In the last few decades Shigella species have shown changes in antibiotic susceptibility patterns. These bacteria progressively show resistance to various antibiotics primarily used in the treatment of diarrhea. ${ }^{10}$ They are resistant to conventional antibiotics such as ampicillin, tetracycline, and trimethoprim-sulfamethoxazole but generally are sensitive to fluoroquinolones. ${ }^{9}$

For cholera, antibiotic treatment is important because it may reduce the frequency of diarrhea and the volume of stools excreted by the patient. ${ }^{8}$ For more than 30 years tetracycline had been the drug of choice for the treatment of cholera. To date no significant numbers of Vibrio cholerae resistant to this antibiotic have been found in Indonesia. In contrast, increased resistance rates to several antibiotics have been found in V. parahaemolyticus. ${ }^{9}$ For patients with diarrhea in developing countries, laboratory investigations, comprising bacterial culture and antibiotic resistance test, are rarely performed, because of the high cost of the investigations. Patients usually receive antibiotic treatment on the basis of clinical signs and symptoms of diarrhea without laboratory confirmation.

The purpose of this study was to determine the antibiotic resistance patterns of several 
diarrhea-causing enteric bacteria that are frequently found in Indonesia, particularly Salmonella, Shigella and Vibrio. Understanding the antibiotic resistance patterns of these pathogens is important, because it may guide empirical treatment in the framework of reducing inapproriate antibiotic use.

\section{METHODS}

Study subjects and location. This study was conducted on patients with diarrhea who attended Community Health Center, South Jakarta, Indonesia, from September 2011 until May 2013. Diarrhea was defined as three or more loose stools during the previous 24 hours. ${ }^{11}$

Informed consent and patient information. Before sample collection, signed informed consent for voluntary participation in the study was requested from the patient or guardian (in case of a child). After obtaining consent, a clinical questionnaire was completely filled out by study personel. Information on personal data and the disease of the patient was recorded by health personel appointed for this task, followed by collection of a stool specimen. The data collected from the subjects comprised age, gender, clinical signs and symptoms, and stool samples or rectal swabs for bacterial culture and antibiotic susceptibility testing

\section{Bacteriological procedures Media.}

The culture media used in this study consisted of xylose-lysine-deoxycholate agar (XLD), MacConkey agar (MAC), Salmonella-Shigella agar (SS), and thiosulfate citrate bile salts sucrose agar (TCBS). All media were obtained from DIFCO, Becton Dickinson, Sparks, MD, and prepared according to previously described methods ${ }^{12,13}$

\section{Study material and culture process}

Rectal swab was collected from patient with diarrhea who attended the Community Health Center. The sample was taken irrespective of disease severity (mild, moderate, or severe). Rectal swab was collected at the time of attendance and before administration of antibiotics. Care was taken to collect the swab before the fourth day of illness, since after four days the bacterial population would have decreased, presumably resulting in a false negative. Rectal swab was placed in Cary Blair transport medium and stored in a refrigerator until transported to the laboratory. The samples were transported under cold conditions by placing them in a thermos bottle. On arrival at the laboratory the rectal swabs were plated onto MAC, SS, XLD and TCBS. The agar plates were incubated aerobically at $37^{\circ} \mathrm{C}$ for $18-24$ hours. Suspected colonies were picked and grown in biochemical media for identification and characterization ${ }^{12,13}$ Serological tests for confirmation were done on each bacterial species isolated using specific antiserum (DIFCO, Becton Dickinson, Sparks, MD).

\section{Antibiotic susceptibility testing}

Bacterial isolates were subsequently subjected to antibiotic susceptibility testing against ampicillin (Am), chloramphenicol (C), tetracycline (Te), trimethoprim sulfamethoxazole (Sxt), ceftriaxone (Cro), ciprofloxacin (Cip), norfloxacin (Nor) and nalidixic acid ( $\mathrm{Na}$ ), The test was performed using the disk diffusion method in accordance with the guidelines of Clinical and Laboratoy Standards Institute. ${ }^{14}$ The antibiotic disks used in this test were obtained from Becton Dickinson and Company, Cockeysville, MA, USA. Escherichia coli ATCC 25922 and Staphylococcus aureus ATCC 25923 were included in the test as control strains. The test result was read by measuring the inhibition zone demonstrated by the culture. Determination of sensitive, resistant or intermediate was in accordance with established standards. ${ }^{14}$

\section{RESULTS}

Overall, 150 rectal swab specimens were collected from patients with diarrhea of all ages without regard to disease severity. From these rectal swabs the isolated enteric pathogenic bacteria consisted of Shigella (11.4\%), Salmonella $(6.6 \%)$ and Vibrio $(2.7 \%)$ species. Shigella strains isolated were $S$. dysenteriae $(0.7 \%), S$. flexneri (6.7\%), S. sonnei (2.7\%) and S. boydii $(1.3 \%)$. Salmonella sp isolated consisted of nontyphoid Salmonella and S. typhi, with percentages of $5.3 \%$ and $1.3 \%$, respectively. The remaining 
isolates were species of Vibrio, namely Vibrio non-01 $(2.0 \%)$ and $V$. parahaemolyticus $(0.7 \%)$ (Table 1).

Results of suceptibility test showed variable resistance among the various bacterial isolates. Of the Shigella species, $S$. flexneri showed the highest resistance rate (80\%-90\%) to ampicillin, chloramphenicol, tetracycline and trimethoprim-sulfamethoxazole. S. sonnei and $\mathrm{S}$. boydii were mostly resistant to tetracycline and trimethoprim-sulfamethoxazole (75\%$100 \%)$, while all $S$. dysenteriae tested (100\%) showed resistance to chloramphenicol and trimethoprim-sulfamethoxazole (Table 1). For non-typhoid Salmonella, resistance to ampicillin and tetracycline comprised more than half $(62.5 \%)$ of the isolates, however many were still sensitive to chloramphenicol and trimethoprimsulfamethoxazole ( $75 \%$ and $87.5 \%$, respectively). For S.typhi no isolates were encountered that were resistant to the antibiotics tested. Vibrio cholera was not found in this study, but of the Vibrio non-01 and V. parahaemolyticus that were isolated, all were resistant to ampicillin (100\%) but sensitive to the other antibiotics.

\section{DISCUSSION}

Resistance to antibiotics may result in changes in virulence of microorganisms and poor response to empirical antibiotic treatment, because the microorganisms are already resistant to the antibiotic in question. Infections caused by antibiotic-resistant microorganisms tend to lead to a longer or a more severe course of the disease, in comparison with infections by bacteria that are still sensitive to antibiotics.

In recent years an increased incidence of infections have been reported, and also multiantibiotic resistance by non-typhoid Salmonella. ${ }^{15,16}$ They stated on the basis of their study results that of all isolated non-typhoid Salmonella serotypes, $S$. Newport was the most resistant to tetracycline, although it was still sensitive to the other antibiotics tested. The majority of the multiresistant serotypes were S. Typhimurium and S. Hadar. Overall, among the isolated and tested non-typhoid Salmonella species in the study of Bukitwetan et $\mathrm{al}^{16}$ many were multiresistant, as had also been reported by other investigators. ${ }^{15}$ In our study, the nontyphoid Salmonella species obtained were on average resistant to four first-line antibiotics that are commonly used in therapy and 20\% of these were even resistant to nalidixic acid (Table 1). However, only a small percentage of the non-typhoid Salmonella were resistant to chloramphenicol, an antibiotic that had previously been the drug of choice for Salmonella infections, particularly S. typhi.

S. typhi species which we isolated did not show resistance to the eight antibiotics tested, as they were sensitive to all. However, because of the extremely small number of isolates that we obtained, viz. only two (1.3\%), this does not constitute a general picture of the antibiotic sensitivity status of S. typhi in Jakarta. On the other hand, the report of Ochiai et $\mathrm{al}^{17}$ stated that in Indonesia, with an S. typhi isolation rate of $3.31 \%$, no antibiotic-resistant $S$. typhi was found, as is the case with China. This situation is very different from that of $S$. typhi from Vietnam, Pakistan, and India, where many $S$. typhi isolates are already resistant to antibiotics, and even show multidrug resistance (MDR), i.e. to ampicillin, chloramphenicol and trimethropimsulfamethoxazole, the percentages being $7 \%$ in India and up to $65 \%$ in Pakistan17. The presence of MDR accompanied by resistance to fluoroquinolones and nalidixic acid, which is developing rapidly in Vietnam, results in problems and difficulties in the treatment of typhoid fever. In 2004 it was reported that isolates of $S$. typhi in Vietnam, which in the previous five years had a resistance rate of $87 \%$ to nalidixic acid, in that year had a resistance rate of up to $97 \% 18$. Patients with S. typhi infections resistant to nalidixic acid show a poor clinical response with a therapeutic failure rate of up to $36 \%$ accompanied by a prolonged fecal carrier state. Although in South Vietnam MDR in S. typhi has been reportedly high in the last 13 years or more, there are reports that in other regions isolates of $S$. typhi are encountered that are again sensitive to chloramphenicol, although in general in other Asian countries the MDR rate of S. typhi is still high. ${ }^{17-19}$

During the last few years no cholera epidemic has been reported in Indonesia and 
the prevalence of cholera is not high, namely around $3 \%$. In spite of that, cholera, which causes acute diarrhea, is still considered to be a health hazard in the under-fives, particularly babies younger than 1 year of age 20 . In our present study no $V$. cholerae 01 was found. This may have been due to an inadequate sample size that did not allow the isolation of $V$. cholerae 01, whose current incidence tends to be low, namely only $0.5 / 1000 /$ year 20 . Other isolated Vibrio species were $V$. cholerae non-01 (2.0\%) and $V$. parahaemolyticus $(0.7 \%)$. Both Vibrio species are in general still sensitive to all tested antibiotics, except ampicillin, to which they were fully resistant (100\%). Agtini et $\mathrm{al}^{20}$ reported that in a survey conducted in Jakarta, $>90 \%$ of isolates of $V$. cholerae 01 were still sensitive to trimethoprim-sulfamethoxazole, tetracycline, and chloramphenicol, besides fluoroquinolones. However, although they successfully isolated noncholera bacteria, Agtini et al ${ }^{20}$ in their reports did not mention the antibiotic sensitivity patterns of these bacterial species. Antibiotic resistance of $\mathrm{V}$. cholerae non-01 and V. parahaemolyticus was reported by Tjaniadi et $\mathrm{al}^{21}$. It was stated that antibiotic resistance in $V$. cholerae non-01 was from year to year clearly increasing in frequency with regard to antibiotics commonly used in the treatment of diarrhea in Indonesia. According to the report ${ }^{21}$, V. parahaemolyticus also showed an increasing frequency of antibiotic resistance, although its pattern was slightly different from that found in V. cholerae non-01. $V$. parahaemolyticus was still sensitive to most of the antibiotics, except for a few number (3$15 \%$ ) that were resistant to tetracycline and chloramphenicol, while to ampicillin all isolates $(100 \%)$ were already resistant. This situation is similar to that found in our study, so that it may be stated that in the last 10 years there have not been many changes in the antibiotic susceptibility pattern of V. parahaemolyticus.

Shigella is the main cause of diarrhea leading to high mortality in developing countries and consistently associated with the syndrome of clinical dysentery, prolonged diarrheal episodes and persistent diarrhea. ${ }^{9}$ Episodes of dysentery are also a risk factor for malnutrition and growth disturbances in children. Antibiotic resistance of these bacteria is developing progressively in Asian, African and Latin American countries. ${ }^{9}$ The study of Kosek et al ${ }^{9}$ reported that overall the isolates of Shigella obtained (63\%-83\%) were already resistant to ampicillin, chloramphenicol, trimethoprim-sulfamethoxazole, tetracycline and erythromycin, but were in general still sensitive to quinolones and ceftriaxon. Similar antibiotic resistance patterns of Shigella have also been reported by other investigators. ${ }^{21-23}$

In our study, among the isolates of Shigella that we obtained and of which we tested the antibiotic sensitivity, all showed resistance to the main antibiotics, i.e. ampicillin, chloramphenicol, tetracycline and trimethoprimsulfamethoxazole. However, different serotypes had different sensitivity patterns. All Shigella serotypes were already resistant to trimethoprim-sulfamethoxazole except for S. flexneri (90\% resistant), the other serotypes, namely $S$. dysenteriae, $S$, boydii and $S$. sonnei, were all $(100 \%)$ resistant to trimethoprimsulfamethoxazole (Table 1). Of the four serotypes that could be isolated, S. flexneri and S. sonnei showed multi-antibiotic resistance, namely to ampicillin, chloramphenicol, tetracycline and trimethoprim-sulfamethoxazole. To other antibiotics such as the quinolones ciprofloxacin, norfloxacin, nalidixic acid, and also to ceftriaxone, all Shigella isolates were still sensitive.

The survey conducted by Agtini et a ${ }^{20}$ in North Jakarta reported that more than $73 \%$ isolates of S. flexneri were resistant to the four antibiotics as in our study. Apparently during the last few years there have not been many changes in the antibiotic sensitivity patterns of $S$. flexneri and other Shigella species in Jakarta. Because of the high frequency of antibiotic resistance of Shigella species to those four antibiotics, they cannot be used anymore for the treatment of shigellosis. Although there are recommendations to give antibiotic treatment to shigellosis in children, the main concern is the selection of antibiotics to be given in the treatment, in view of the great number of resistant Shigella species. The use of fluoroquinolones in children with shigellosis is still controversial, and therefore alternative drugs should be looked for. According to the report of Herwana et al ${ }^{24}$ and our own study 
results, no resistance of Shigella to nalidixic acid has been found, so that nalidixic acid is currently the antibiotic of choice in the treatment of shigellosis in children in Jakarta or even in Indonesia. Except for various reports on the resistance of Shigella species, from our study results it is difficult to come to a conclusion about the antibiotics susceptibility of $S$. dysenteriae and $S$. boydii, because of the small numbers of isolates that we obtained. For Vibrio species there are not many problems in antibiotic treatment, however those antibiotics that a few years ago were in common use for the treatment of shigellosis and salmonellosis, are currently of no benefit, because of the high frequency of resistance in these bacteria.

Although the mechanisms of resistance in organisms have been clearly known, including selective pressure as a result of exposure to antibiotics, the precise role of drug usage in the selection of antibiotic resistance cannot be fully explained yet. Therefore, it is recommended to be careful in the use of antibiotics for the treatment of infectious disease.

\section{CONCLUSION}

For each of the enteric pathogens the antibiotic resistance pattern should be determined. Understanding the antibiotic resistance patterns of these pathogens is important, because it may guide empirical treatment in the framework of reducing inapproriate antibiotic use. Use of antibiotics should be based on the antibiotic susceptibility tests.

\section{REFERENCES}

1. Travers K, Barza M. Morbidity of infections caused by antimicrobial resistant bacteria. Clin Infect Dis 2002;34 (suppl 3):S131-4.

2. Mulvey MR, Simor AE. Antimicrobial resistance in hospitals: how concerned should we be? CMAJ 2009;180:408-15.

3. Fauci AS, Morens DM. The perpetual challenge of infectious diseases. $N$ Engl J Med 2012; 366:454-61.

4. Brooks JT, Ochieng JB, Kumar L, et al. Surveillance for bacterial diarrhea and antimi- crobial resistance in rural western Kenya 1997-2003. Clin Infect Dis 2006;43:393401.

5. Chiu C-H, Su L-H, Chu C. Salmonella enterica serotype Choleraesuis: epidemiology, pathogenesis, clinical disease, and treatment. J Clin Microbiol 2004;17:311-22.

6. Black RE. Diarrheal diseases. In: Nelson KE, Williams CM, Graham NMH, editors, Infectious Disease Epidemiology: theory and practice. Gaithersburg, MD: Aspen Publishers, 2001.

7. Rabatsky-Her T, Whichard J, Rossiter S, et al. Multidrug-resistant strains of Salmonella enterica Typhimurium, United States, 1997-1998. Emerg Infect Dis 2004;10:795801.

8. Orman BE, Pineiro SA, Aeduino S, et al. Evolution of multiresistance in nontyphoid Salmonella serovars from 1984 to 1998 in Argentina. Antimicrob Agents Chemother 2002;46:3963-70.

9. Kosek M, Yori PP, Pan WK, Olortegui MP, Gilman RH, Perez J, Chavez CB, et al. Epidemiology of highly endemic multiply antibiotic-resistant Shigellosis in children in the Peruvian Amazon. Pediatrics 2008;122:e541-9

10. Niyogi SK. Shigellosis. J Microbiol 2005; 43:133-142.

11. DuPont HL. Bacterial diarrhea. N Engl J Med 2009; 361:1560-9.

12. Bopp CA, Brenner FW, Fields PI, Wells JG, Strockbine NA. Escherichia, Shigella, and Salmonella. In: Murray PR, Baron EJ, Jorgensen $\mathrm{JH}$, Pfaller MA,Yolken RH, editors. Manual of Clinical Microbiology, 8th ed. Washington DC: American Society for Microbiology: 2003. p. 654-71

13. Farmer JJ, Janda JM, Birkhead K. Vibrio. In: Murray PR, Baron EJ, Jorgensen JH, Pfaller MA, Yolken RH, editors. Manual of Clinical Microbiology, 8th ed. Washington DC: American Society for Microbiology:2003. p. 706-18.

14. Clinical and Laboratory Standards Institute. Performance standards for antimicrobial susceptibility testing. Sixteenth 
Informational Supplement CLSI Document M100-S16. Wayne, Pa: Clinical and Laboratory Standards Institute, 2006

15. Edelstein M, Pimkin M, Dmitrachenko T, et al. Multiple outbreaks of nosocomial salmonellosis in Russia and Belarus caused by a single clone of Salmonella enterica serovar Typhimurium producing an extended-spectrum $\beta$-lactamase. Antimicrob Agents Chemother 2004; 48:2808-15.

16. Bukitwetan P, Suryawidjaja JE, Salim Och, Hidayat A, Herwana E, Lesmana M. Serovar distribution and antibiotic susceptibility of nontyphoidal Salmonella isolated from pediatric patients in Jakarta, Indonesia. Southeast Asian J Trop Med Public Health 2007; 38:1088-94.

17. Ochiai RL, Acosta CJ, Danovaro-Holliday MC, et al. A study of typhoid fever in five Asian countries: disease burden and implications for controls. Bull World Health Organ 2008;86:260-8.

18. Tran TC, Campbell JI, Galindo CM, et al. Antimicrobial drug resistance of Salmonella enterica serovar Typhi in Asia and molecular mechanism of reduced susceptibility to the fluoroquinolones. Antimicrob Agents Chemother 2007; 51:4315-23.

19. Parry CM, Ho VA, Ohuong Ie T, et al. Randomized controlled comparison of ofloxacin, azithromycin, and an ofloxacin-azithromycin combination for treatment of multidrug-resistant and nalidixic acid- resistant typhoid fever. Antimicrob Agents Chemother 2007; 51:819-25.

20.Agtini MD, Soeharno R, Lesmana M, et al. The burden of diarrhea, shigellosis, and cholera in North Jakarta, Indonesia: findings from 24 months surveillance. BMC Infect Dis 2005; 17: 341-50.

21.Tjaniadi P, Lesmana M, Subekti D, et al. Antimicrobial resistance of bacterial pathogens associated with diarrheal parients in Indonesia. Am J Trop Med Hyg 2003; 68: 666-70.

22.Jafari F, Hamidian M, Rezadenbashi M, et al. Prevalence and antimicrobial resistance of diarrheagenic Escherichia coli and Shigella species associated with acute diarrhea in Tehran, Iran. Can J Infect Dis Med Microbiol
2009; 20:e56-62.

23. Fulla N, Prado V, Duran C, Lagos R, Levine MM. Surveillance for antimicrobial resistance profiles among Shigella species isolated from a semirural community in the northern administrative area of Santiago, Chile. Am J Trop Med Hyg 2005; 72:851-4.

24.Herwana E, Surjawidjaja JE, Salim Och, Indriani N, Bukitwetan P, Lesmana M. Shigella-associated diarrhea in children in South Jakarta, Indonesia. Southeast Asian J Trop Med Public Health 2010; 41:418-25 